\title{
Quantifying Declines in Livestock Due to Land Subdivision
}

\author{
Randall B. Boone, ${ }^{1}$ Shauna B. BurnSilver, ${ }^{1}$ Philip K. Thornton, ${ }^{2,3}$ \\ Jeffrey S. Worden, ${ }^{1,2}$ and Kathleen A. Galvin ${ }^{1,4}$ \\ Authors are ${ }^{1}$ Natural Resource Ecology Laboratory, Colorado State University, Fort Collins, CO 80523-1499; ${ }^{2}$ International \\ Livestock Research Institute, Nairobi, Kenya; ${ }^{3}$ Institute of Atmospheric and Environmental Sciences, School of Geosciences, \\ University of Edinburgh, Edinburgh, United Kingdom; and ${ }^{4}$ Department of Anthropology, \\ Colorado State University, Fort Collins, CO 80523-1787.
}

\begin{abstract}
In Kajiado District, Kenya, ranches held communally by Maasai are being subdivided into individually owned parcels. Livestock owners know that herds on parcels that are too small cannot be viable, but the decline in the capacity of parcels to support livestock has not been quantified. We used ecosystem modeling to represent the effects of subdivision as Maasai group ranches were divided into 196, 10, 5, 3, and $1 \mathrm{~km}^{2}$ parcels. Within the spatially explicit, process-based SAVANNA ecosystem model, we used maps that constrained the movements of livestock to be within parcels. We also modeled cooperative grazing associations, giving groups of herders access to parcels composed of dispersed or contiguous $1 \mathrm{~km}^{2}$ parcels. Vegetatively productive areas had higher carrying capacities when isolated because resident animals did not compete with animals moving in seasonally from other areas. In a ranch of low but heterogeneous productivity, we saw a steady decline in capacity under subdivision, until $25 \%$ fewer livestock could be supported on the ranch of $1 \mathrm{~km}^{2}$ parcels relative to the intact ranch. On a ranch with both low productivity and heterogeneity, 20\% fewer livestock were supported when parcels were still $10 \mathrm{~km}^{2}$. The most productive ranch studied saw small population changes with subdivision. Participation in grazing associations was helpful in the ranch intermediate in productivity and heterogeneity, but not other ranches. Subdivision of Kajiado lands might be inevitable, but our results show the relative benefits to stakeholders if land owners and policy makers act to maintain open or flexible access to individually held parcels.
\end{abstract}

\section{Resumen}

En el Distrito Kajiado, Kenya, los ranchos manejados comunalmente por los Massai están siendo subdivididos en parcelas de propiedad individual. Los propietarios de ganado saben que los hatos en parcelas muy pequeñas no son viables, pero la disminución de la capacidad de las parcelas para sostener el ganado no ha sido cuantificada. Usamos el modelaje de ecosistemas para representar los efectos de la subdivisión de cómo el grupo de ranchos Massai fueron divididos en parcelas de 196, 10, 5, 3 y $1 \mathrm{~km}^{2}$. Dentro de la explicitud espacial del modelo de ecosistemas SAVANNA, basado en procesos, usamos mapas que limitaban los movimientos del ganado dentro de las parcelas. También modelamos las asociaciones cooperativas de apacentamiento, dando, a grupos de pastores, acceso a parcelas compuestas de parcelas de $1 \mathrm{~km}^{2}$ dispersas o contiguas. Cuando se aislaron, las áreas vegetativamente productivas tuvieron mayores capacidades de carga animal porque los animales residentes no compitieron con animales moviéndose estacionalmente de otras áreas. En un rancho de productividad baja pero heterogénea, observamos una disminución gradual de su capacidad bajo la subdivisión, hasta que $25 \%$ menos del ganado pudo ser sostenido en el rancho de parcelas de $1 \mathrm{~km}^{2}$ en relación al rancho intacto. En un rancho con baja productividad y heterogeneidad, $20 \%$ menos ganado fue soportado aun cuando las parcelas permanecieron de $10 \mathrm{~km}^{2}$. El rancho más productivo estudiado vio pocos cambios en la población por la subdivisión. La participación en asociaciones de apacentamiento fue útil en el rancho intermedio en productividad y heterogeneidad, pero no los otros ranchos. La subdivisión de las tierras del Kajiado puede ser inevitable, pero nuestros resultados muestran los beneficios relativos para los usuarios, si los propietarios de la tierra y los que dictan las políticas actúan para mantener un acceso abierto o flexible a las parcelas manejadas individualmente.

Key Words: fragmentation, heterogeneity, Kajiado District, Kenya, Maasai, movement, SAvanNA, sedentary

\section{INTRODUCTION}

Research was partially supported by the Global Livestock Collaborative Research Support of the Office of Agriculture and Food Security, Global Bureau, United States Agency for International Development, to D. M. Swift, M. B. Coughenour, and K.A.G, under grant PCE-G-98-00036-00, and by a grant from the U.S. National Science Foundation Biocomplexity program to N. T. Hobbs et al. under grant 0119618.

Correspondence: Dr Randall B. Boone, 1499 Campus Delivery—B234 NESB, Natural Resource Ecology Laboratory, Colorado State University, Fort Collins, CO 80523-1499 Email: rboone@nrel.colostate.edu

Manuscript received 9 September 2004; manuscript accepted 18 June 2005.
Semi-arid and arid rangelands that are generally too dry to support rain-fed agriculture but have vegetation comprise about $25 \%$ of the landscapes of the world, excluding Antarctica (reviewed in Groombridge 1992). Twenty million or more households make their living as pastoralists on these lands, and ten times as many obtain a significant source of income from raising livestock (De Haan et al. 1997). Pastoral livestock inhabit landscapes that are spatially heterogeneous and have forage patches that pulse in their value to animals through time (Pickup and Stafford Smith 1993). Mobile pastoralists evolved 
movement patterns that maximized, to the degree possible, their aggregate access to ephemeral forage patches. Today, in pastoral communities across Africa, changes in land tenure policy and socioeconomic pressures are causing pastoralists to decrease their mobility or become sedentary (Niamir-Fuller and Turner 1999; FAO 2001a). Whereas in the past a herder might have moved seasonally to access the best forage within a 5000 $\mathrm{km}^{2}$ area, today the pastoralist-and all the pastoralist's neighbors-might be restricted to the $80 \mathrm{~km}^{2}$ area within 5 $\mathrm{km}$ of his village. For more than a decade, researchers have been urging that pastoral mobility be preserved, to maintain livestock productivity and ecosystem integrity (e.g., Behnke and Scoones 1993). Pastoralists also recognize that shrinking access to land reduces their options to find forage (Galaty 1994). Theory suggests that the capacity of a heterogeneous parcel of land to support livestock decreases as a power of the square root of the area that is accessible (Ritchie and Olff 1999). But only now are we quantifying the likely declines in numbers of animals isolated landscape patches can support over the longterm (Boone and Hobbs 2004). In this paper we use ecological modeling to estimate the changes in carrying capacity Maasai pastoralists in Kajiado District, Kenya, might expect as their land is subdivided.

Historically, Maasai pastoralists moved seasonally within large socioculturally defined parcels of land known as sections (e.g., there are eight in Kajiado District, averaging $2731 \mathrm{~km}^{2}$; Ole Katampoi et al. 1990). In the late 1960s and early 1970s, the Kenyan government in cooperation with international organizations began a process of adjudicating Kajiado District (Kimani and Pickard 1998) into what are now 52 group ranches, averaging about $340 \mathrm{~km}^{2}$. Group ranches were formed to allow members to gain collective group title to their land, improve livestock production, better match the capacity of ranches to support livestock (which individuals own), and encourage the development of infrastructure for both livestock (e.g., dipping tanks, water sources) and people (e.g., schools). Some of these goals have been met, but most have not (Bekure et al. 1991). The failure of group ranch formation to reach its goals has been described elsewhere (e.g., Galaty 1994; Kimani and Pickard 1998), and for brevity will not be expanded upon here. Division of grazing lands began a new phase in the mid1970s, as group ranches were subdivided into private parcels, a process that was sanctioned by the government in 1983 (Grandin 1989). That process continues today, with group ranch committees voting to subdivide entire ranches into small parcels of 24 to 40 ha to be dispersed among ranch members. The trend is towards increasing fragmentation of the rangelands; however, pastoral households do continue to negotiate land access across sectional and group ranch boundaries, particularly in times of drought (Rutten 1992; BurnSilver, unpublished data; Worden, unpublished data). In this paper we focus upon a specific effect of progressive land division (i.e., from Maasai sections, to formation of the group ranches, and now into smaller private parcels), the decline in livestock carrying capacity irrespective of habitat loss.

Subdivision is a contentious and hotly debated issue. Members of ranches in particularly dry areas (e.g., southern Kajiado) are apprehensive that subdivision of their land into parcels that are used exclusively by individual owners will reduce the number of livestock their lands can support (Galaty
1994). During extensive field research, we have been told that the political, tenurial, and social pressures to subdivide are too great to withstand and that subdivision is now inevitable (BurnSilver, unpublished data). Pressures to subdivide are: internal, with group ranch members seeking title to parcels as a means of retaining land and impatient with the pitfalls of group ranch membership as described above; and external, with the Kenyan government seeking privatization of land, seen as initial steps to development. There are a number of ways in which group ranches can be subdivided, varying from a straightforward division based on the ratio of group ranch lands to the number of members, to arrangements under which members receive small parcels for permanent settlement but core areas remain open to communal grazing, to the use of grazing associations where multiple households, with either contiguous or separated parcels, band together for cooperative grazing. In that light, we sought to quantify the impacts and tradeoffs of subdivision under these scenarios, identifying potential effects on livestock production under straightforward subdivision (1 $\mathrm{km}^{2}$ parcels per household), partial subdivision $\left(196 \mathrm{~km}^{2}\right.$ blocks), and parcel sharing in formal or informal grazing associations, which pastoralists faced with food insecurity and limited grazing options in subdivided ranches have already begun to form. We quantified effects on four group ranches that varied in their landscape heterogeneity, including vegetation, and in their rainfall and general productivity.

\section{STUDY AREA}

Kajiado is a semi-arid district in southwestern Kenya $\left(36^{\circ} 0^{\prime} \mathrm{E}\right.$ to $37^{\circ} 55^{\prime} \mathrm{E}, 1^{\circ} 1^{\prime} \mathrm{S}$ to $\left.3^{\circ} 3^{\prime} \mathrm{S}\right)$ totaling $21105 \mathrm{~km}^{2}$. Our study area (Fig. 1) is the southern half of the district $\left(10746 \mathrm{~km}^{2}\right)$ and includes world-renowned Amboseli National Park $\left(392 \mathrm{~km}^{2}\right)$. Elevations range from $790 \mathrm{~m}$ along the southeastern border shared with Tsavo National Park West to $2159 \mathrm{~m}$ within the Chyulu Hills (Fig. 1). Brown calcareous clay loams and ash and pumice soils dominate the area, with Quaternary sediments underlying Amboseli National Park (Ole Katampoi et al. 1990). Precipitation is bimodal and variable (coefficient of variation [CV] of annual rainfall, 1969-1998, 27\%), but generally ranges between 400 and $800 \mathrm{~mm}$ annually within the study area, with the higher amounts confined to the slopes of Mount Kilimanjaro and the Chyulu Hills. Plant communities in the region include grasslands, with red oat grass (Themeda triandra Forssk) as an important plant species, and wooded grasslands and bushlands, with acacia trees and shrubs (e.g., Acacia drepanolobium Sjöstedt). The district includes wildlife populations that attract tourists from around the world. Many of these wildlife disperse from Amboseli National Park in the wet season for grazing on surrounding group ranch lands, then collapse back to the swamps and other permanent water sources of Amboseli in the dry season. Based on the CV in annual rainfall and livestock and wildlife population estimates from aerial surveys, large herbivore biomass appears related to vegetation productivity, so that along the continuum of nonequilibrium to equilibrium rangeland dynamics, the area tends more toward the later (Ellis 1993). On the basis of census data, we estimated that in 2002 about 52000 Maasai inhabited the study area, with high human population growth 
and in-migration by non-Maasai. Resident Maasai increasingly employ combinations of livelihood strategies, but the foundation of the economy is livestock raising. Despite economic diversification, many residents of Kajiado District live below the Kenyan poverty line (GoK 2003).

We focused our analyses on four group ranches, Eselenkei (Es in Fig. 1), Imbirikani (Im), Osilalei (Os), and Olgulului/ Lolarashi, hereafter referred to as Olgulului $(\mathrm{Ol})$. The ranches were selected for long term study because: 1) they vary in productivity, from the most productive Osilalei to least productive Olgulului; 2) their differing topography, from relatively homogeneous Olgulului to Imbirikani, which contains the Chyulu Hills; and most importantly 3) their different histories of subdivision. Osilalei Group Ranch was subdivided in 1981, whereas the other three group ranches are as yet not subdivided. Partial or complete subdivision is imminent in Imbirikani and Olgulului, and is planned in Eselenkei.

\section{METHODS}

\section{Rationale}

Several workshops were held in 2001 and 2002 in which local group ranch members, land managers such as members of the Kenya Wildlife Service, and research scientists such as members of the African Conservation Centre, were asked to identify the issues they believed were most threatening to the long-term sustainability of their varied livestock, human, and conservation interests. The issue of most concern and one that was shared across all groups was land subdivision and associated sedentarization effects. We therefore used ecosystem and household simulation to quantify some effects of subdivision, to inform Maasai of the tradeoffs associated with using land exclusively, and to inform Kenyan policy makers of inputs that might be required to offset losses associated with sedentarization.

\section{Modeling Tools}

Quantifying changes in livestock production in Kajiado required that we use a model that simulated large herbivore and vegetation dynamics using process-based methods, in a spatially and temporally explicit way. We used the SAVANNA Modeling System, initially developed for work in the Turkana District of Kenya (Coughenour 1985), with many subsequent improvements and applications (e.g., Coughenour 1992; Boone et al. 2002; Boone et al. 2004). SAVANNA is a series of interconnected FORTRAN computer programs that use process-based methods to model primary ecosystem interactions in arid and semi-arid landscapes, simulating functional groups of plants and animals (e.g., palatable grass, cattle, elephants [Loxodonta africana]).

SAVANNA predicts water and nitrogen availability for plants, within cells dividing the landscape modeled. Based upon competition for water, light, and nutrients, quantities of photosynthate are calculated for plant functional groups. Photosynthate is allocated to leaves, stems, and roots using plant allometrics, yielding estimates of primary production. Changes in plant populations are derived from reproduction related to primary production. At each weekly time-step of the model, plants might, for example, produce seeds that become established, grow into older age classes, outcompete other plant

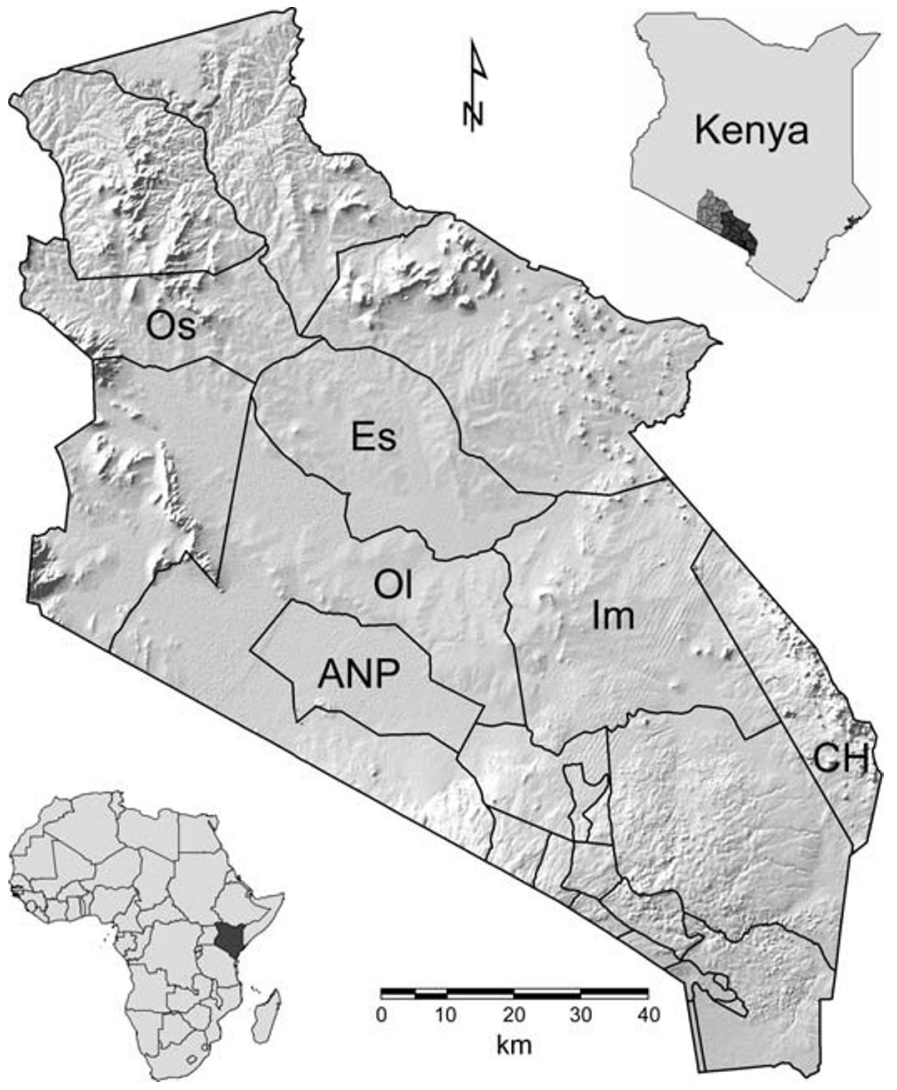

Figure 1. Kajiado District is in southwestern Kenya (see insets), and the southern half of the district formed the study area. Focal group ranches are labeled: Eselenkei (Es, $\left.797 \mathrm{~km}^{2}\right)$, Imbirikani (Im, $\left.1361 \mathrm{~km}^{2}\right)$, Olgulului/Lolarashi (0I, $1566 \mathrm{~km}^{2}$ ), and Osilalei (0s, $535 \mathrm{~km}^{2}$ ). Also labeled are Amboseli National Park (ANP) and Chyulu Hills Conservation Area $(\mathrm{CH})$. Group ranch boundaries are in black, and topography is indicated with shading.

functional groups, or die. Animals feed upon the available vegetation, depending upon dietary preferences and consumption rates. The energy they gain is reduced by energy expenditures, such as basal metabolism, gestation, and lactation. Net energy remaining causes weight change, with weights reflected in condition indices. A habitat suitability index is calculated for each cell in the landscape, at weekly intervals and for each animal functional group. Individuals in the populations are distributed on the landscape based on these indices. The SAVANNA model uses a weekly processing interval, and runs are typically from 10 to 100 years. For more detail on SaVANNA, see Boone (2000).

\section{Adapting Savanna to Southern Kajiado District}

Plant and animal functional groups must be defined for an area prior to adapting the SAVANNA model, based upon the scenarios to be addressed and balancing the need for detail vs. the costs of model parameterization and execution. An existing application of SAVANNA (version 4e) had been applied to Kajiado and used in simple analyses. That application was updated using a newer version of Savanna (4Lc), and modified (e.g., it uses better spatial data than was previously available, and was more rigorously parameterized). There are seven plant functional groups modeled: palatable grasses, palatable forbs, unpalatable 
Table 1. Example sources used to parameterize Savanna to southern Kajiado District.

\begin{tabular}{lc}
\hline Parameter Group & Example Sources \\
\hline Plant phenology, biomass & Ndawula-Senyimba 1972; McNaughton 1985; \\
Plant allometrics and growth & Fourie et al. 1991; Boar et al. 1999 \\
& et al. 1989; Coughenour et al. 1990; \\
& Tewari 1996 \\
Livestock energetics and growth & Bekure et al. 1991; Murray 1995; \\
& Verma et al. 1997 \\
Grazing effects, stocking effects, & Sinclair and Gwynne 1972; Western 1975; \\
and habitat relationships & Van Wijngaarden 1985; Kalemera 1989 \\
Climatic effects & Staples et al. 1942; Mwalyosi 1992; Prins and \\
& van der Jeugd 1993; O'Connor 1994 \\
Human decision making & Homewood and Rodgers 1987; \\
& Bekure et al. 1991; Mwangi 1994; \\
& BurnSilver et al. 2003 \\
\hline
\end{tabular}

grasses and forbs, swamp vegetation, palatable shrubs, unpalatable shrubs, and deciduous woodlands. Nine animal functional groups were used, with six wildlife groups: wildebeest (Connochaetes taurinus), zebra (Equus burchellii), African buffalo (Syncerus caffer), grazing antelope, browsing antelope, and elephants; and three livestock groups-cattle, goats, and sheep. Grazing antelope include Grant's gazelle (Gazella granti), Thomson's gazelle (Gazella thomsoni), impala (Aepyceros melampus), kongoni (Alcelaphus bucelaphus), oryx (Oryx gazella), and waterbuck (Kobus ellipsiprymnus). Browsing antelope include eland (Taurotragus oryx), greater kudu (Tragelaphus strepsiceros), lesser kudu (Tragelaphus imberbis), and gerenuk (Litocranius walleri).

The geographic layers used by SAVANNA include elevation, slope, aspect, vegetation, soils, and water sources. Elevation, slope, and aspect were derived from a digital elevation model. Land cover was a simplified version of the map produced by AfriCover (FAO 2001b), soils were from KenSOTER (Kenya Soil Survey 1995), and water sources were from an edited database from the Ministry of Agriculture. Six distance to water maps were created: for livestock (e.g., pipelines, boreholes, dams) and wildlife (e.g., swamps) in the wet months (April, May, November), the dry months (January, February, July, August, September, October), and in months of transition (March, June, December). Maps called "force maps," were created that allow SAVANNA to limit the distribution of herbivores due to factors other than habitat, such as legal restrictions or fencing. For example, livestock were prevented from grazing within Amboseli National Park (although grazing occurs while animals are being watered, which is nominally allowed). The bulk of the study area was available to most wildlife species, except for being excluded from fenced swamps. Elephant distributions were limited to areas within ca. $35 \mathrm{~km}$ of Amboseli National Park (Ole Katampoi et al. 1990). All geographic data were generalized to $5 \times 5 \mathrm{~km}$ blocks, $2.5 \times$ $2.5 \mathrm{~km}$ blocks, and $1 \times 1 \mathrm{~km}$ blocks. The coarse resolution maps were used early in parameterization. Simulations for the entire study area were at $2.5 \times 2.5 \mathrm{~km}$ resolution, and those at the group ranch level were at $1 \times 1 \mathrm{~km}\left(1 \mathrm{~km}^{2}\right)$ resolution.
Weather data from 47 stations within Kajiado were available from 1969 to 1998, but data were sparse. Monthly rainfall estimates for stations were augmented with values from 1999 to 2002 using rainfall estimates derived from satellite images (Xie and Arkin 1997) and available from ADDS (2004). SAVANNA uses a focal weather station for temperature and other data (e.g., wind speed and relative humidity). We used the Makindu meteorological station, $22 \mathrm{~km}$ northwest of Imbirikani Group Ranch.

Parameters were set in the model based upon a literature review, previous SAVANNA applications (Coughenour 1992; Boone et al. 2002), field work associated with the project (e.g., BurnSilver et al. 2003), another ecosystem model (Toxopeus et al. 1994), and expert opinion. A dated but comprehensive study of Maasai livestock raising in Kajiado, Bekure et al. (1991), was particularly helpful. Individual parameters and their sources are too numerous to cite, but examples can be cited based upon ecological processes (Table 1). Wildlife and livestock populations were taken from 12 aerial surveys conducted by the Kenyan Department of Resource Surveys and Remote Sensing (DRSRS) between 1980 and 2000 (see De Leeuw et al. 1998 for details), and for elephants, SEVP (2002). For the entire study area, we included 17517 wildebeest, 27766 zebra, 1277 buffalo, 31447 grazing antelope, 3968 browsing antelope, 1160 elephants, 235899 cattle, 99424 goats, and 106700 sheep.

The ecosystem model was calibrated until responses were similar to those in the literature or data available (e.g., NPP estimates from satellite imagery [Oesterheld et al. 1998] and a nearby long term study [Kinyamario 1996]). As examples, patterns of seasonal biomass availability from an area studied by Bekure et al. (1991) were compared to those modeled, and distributions of large herbivores were compared to maps for species created using DRSRS aerial survey results. A final assessment of plant phenology compared modeled summed leaf green biomass of herbaceous plants, shrubs, and trees, and greenness indices recorded by satellites. Modeled plant phenology agreed reasonably well with observed greenness based on satellite images (Spearman's $\rho=0.65$ ).

\section{Analyses}

The spatial relationships used to reflect areas available to pastoralists under different subdivision scenarios are summarized in Figure 2. To focus upon the effects of patch isolation and to minimize effects of any errors in parameterization, results were compared between simulations where areas of interest were intact vs. isolated patches; the only difference was the area available to herbivores. A stepwise approach was used, from full study area, to Maasai sections, to group ranches, to parcels. Livestock populations supported on the entire study area were compared to those that could be supported on an area that included much of Ilkisongo Maasai section, and on the remaining portion of the study area (Fig. 2a). Next, the number of livestock supported on isolated group ranches was compared to animals supported on those ranches when the ranches were part of the entire study area (Fig. 2b).

Ongoing subdivision (e.g., division of group ranches into communal grazing areas and private parcels) was simulated using comparisons between livestock populations that could be 
supported on entire group ranches vs. parcels of declining areas of 196, 10, 5, 3, and $1 \mathrm{~km}^{2}$ (Fig. 2c, with Eselenkei Group Ranch shown, but analyses done for Olgulului and Osilalei as well). The largest parcel represents partial subdivision that would leave large areas as intact communal lands, which has been suggested. The remaining parcel areas $(10,5,3$, and $1 \mathrm{~km}^{2}$ ) provided a gradient of responses as parcel area declined to an area three times larger than that individual group ranch members can expect to receive (e.g., $32 \mathrm{ha}$, or $0.32 \mathrm{~km}^{2}$, expected for Imbirikani members), but the finest spatial resolution of the model. We quantified first the carrying capacity of parcels that were comprised of $1 \mathrm{~km}^{2}$ cells neighboring each other (i.e., Fig. 2c, first row), and then second, comprised of individual $1 \mathrm{~km}^{2}$ parcels located randomly within the group ranch, representing parcels owned by members of a grazing association that allowed their livestock to move among parcels owned by the association members (Fig. $2 \mathrm{c}$, second row). We hypothesized that those participating in grazing associations would benefit from access to dispersed grazing parcels comprised of different vegetation communities and exposed to heterogeneous weather effects.

The metric of interest was always the number of animals supported on the group ranch, either as intact or isolated parcels. This was estimated by conducting 20 simulations using randomly placed parcels for each configuration (dark blocks in Fig. 2c), except for the $196 \mathrm{~km}^{2}$ simulations, where only five simulations sampled the ranches well, using blocks of land of $196 \mathrm{~km}^{2}$ haphazardly placed in each group ranch. For example, in the Figure 2c, one simulation was done for the entire group ranch, five for $196 \mathrm{~km}^{2}$ parcels, 20 each for $10,5,3$, and $1 \mathrm{~km}^{2}$ contiguous parcels, and 20 each for 10,5 , and $3 \mathrm{~km}^{2}$ dispersed parcels representing grazing associations, for a total of 146 simulations. Twenty simulations provided sufficiently small standard errors while minimizing simulation times. Each run simulated a period of 24 years, which was the period for which reasonably complete weather data were available. Wildlife populations were held the same each year and with migratory patterns represented correctly in analyses at the group ranch level or below; interpreting 11 mutually interacting wildlife and livestock populations changing in a compensatory way would be confusing and not relevant to our central focus on effects of fragmentation on livestock. Initial livestock populations for areas smaller than group ranches were set using an areaweighted relationship. For example, a simulation of a $10 \mathrm{~km}^{2}$ parcel within a $1000 \mathrm{~km}^{2}$ group ranch would be initialized with $1 \%$ of the number of livestock on the group ranch. In all analyses, animals were assumed to have access to water sources regardless of ownership considerations, so that the presence or absence of a water source within a parcel used exclusively by an owner for grazing did not affect its suitability, except as reflected in energetic costs associated with travel. If parcels were required to contain a water source in these semi-arid areas, a very small fraction of parcels would support livestock and the presence of a water source would be the overwhelming determinant related to effects of fragmentation on livestock. Also, in the group ranch subdivided more than 20 years (Osilalei), pastoralists have maintained travel corridors allowing others access to water without crossing large blocks of privately held lands.

Results are reported as capacities using tropical livestock units (TLUs), which represent $250 \mathrm{~kg}$ of livestock mass,

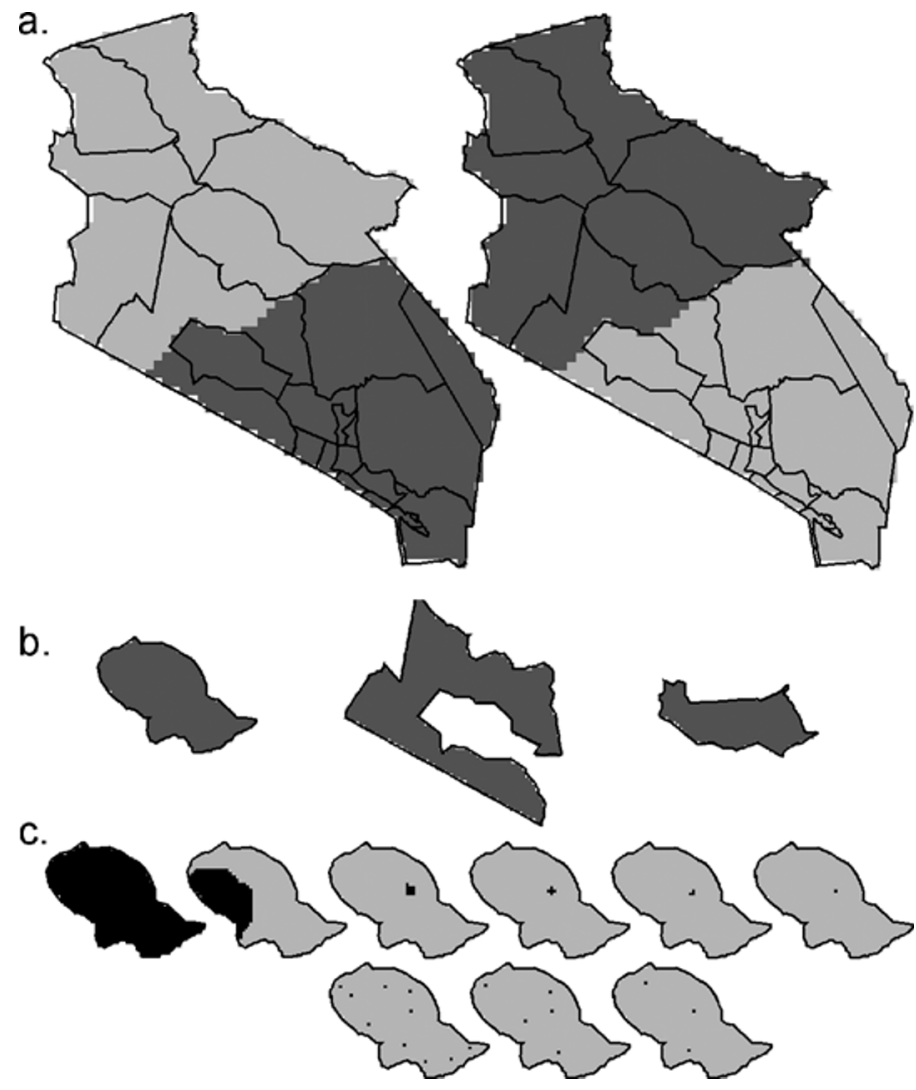

Figure 2. A spatial summary of analysis areas at the same scale, including: (a) much of Ilkisongo Maasai Section in southern Kajiado District (dark gray, left) isolated from the northern portions of the study area; (b) group ranches vs. the entire study area; and (c) comparisons using the group ranches and 196, 10, 5, 3, and $1 \mathrm{~km}^{2}$ areas, including having the areas composed of contiguous or scattered $1 \mathrm{~km}^{2}$ blocks. Each is drawn to scale.

averaged over each 24 year simulation. One-sample t-tests, where parcel capacities were compared to the modeled group ranch capacity, were used to detect significant differences in subdivided carrying capacities vs. capacities of intact group ranches. To avoid confusion, significance of differences between all analyses (e.g., 196, 10, 5, 3, $1 \mathrm{~km}^{2}$ contiguous parcels, and 10,5 , and $3 \mathrm{~km}^{2}$ dispersed parcels) are not shown, but standard error bars indicate dispersion.

\section{RESULTS}

When an area including much of Ilkisongo Maasai Section was isolated from the rest of the study area (Fig. 2a), the results demonstrated the decline in livestock carrying capacity we hypothesized. The solid line (Fig. 3a) reflects total livestock numbers on the area when livestock were able to continue migrating to the north during dry periods. The general response through time is typical, with populations increasing until a drought in the mid-1980s, with declining, and rapid fluctuations representing annual births and deaths of animals. However, when animals were confined to the smaller area throughout the entire simulation, up to 40000 fewer TLUs were supported (Fig. 3a, dotted line). When animals were 


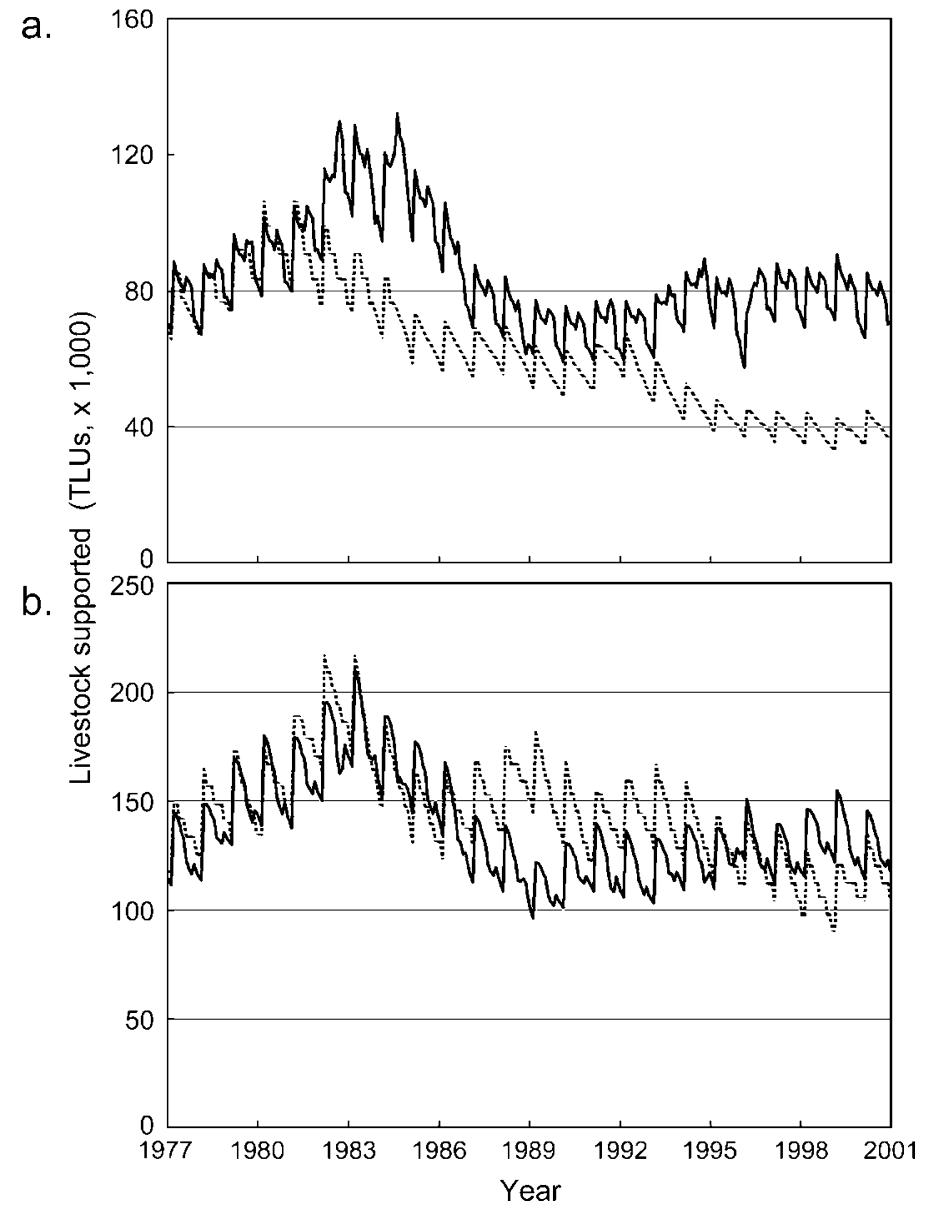

Figure 3. The (a) decline in livestock supported on the southern section of the study area when it is isolated (dotted line) vs. part of the entire study area (solid line). In contrast (b), a small increase in livestock numbers (dotted line) occurred on the remaining northern portion of the study area when it was isolated, vs. having the entire study area intact (solid line). Simulated responses based on the observed weather pattern are shown.

confined to the more productive area to the north, livestock populations increased or changed little (Fig. 3b). Overall, more animals could be supported on the contiguous study area than when it was represented as two isolated patches.

When livestock were confined to Imbirikani Group Ranch, a ranch of moderate productivity, about half the number could be supported, compared to when they had access to the entire study area (Fig. 4a). In sharp contrast, livestock populations in productive Osilalei increased dramatically when the ranch was isolated from the remaining study area (Fig. 4b) —animals in the isolated Osilalei did not have to compete with animals moving in from elsewhere during times of low resources, and livestock prospered. Eventually the capacity of the ranch was exceeded, and then following a drought the population collapsed.

Analyses to compare livestock populations on large grazing areas showed about the same numbers of livestock could be supported on $196 \mathrm{~km}^{2}$ parcels as on intact group ranches (Fig. 5). However, when subdivided and isolated $1 \mathrm{~km}^{2}$ parcels within the group ranches were simulated, Eselenkei Group Ranch supported $25 \%$ fewer livestock than when it was intact,

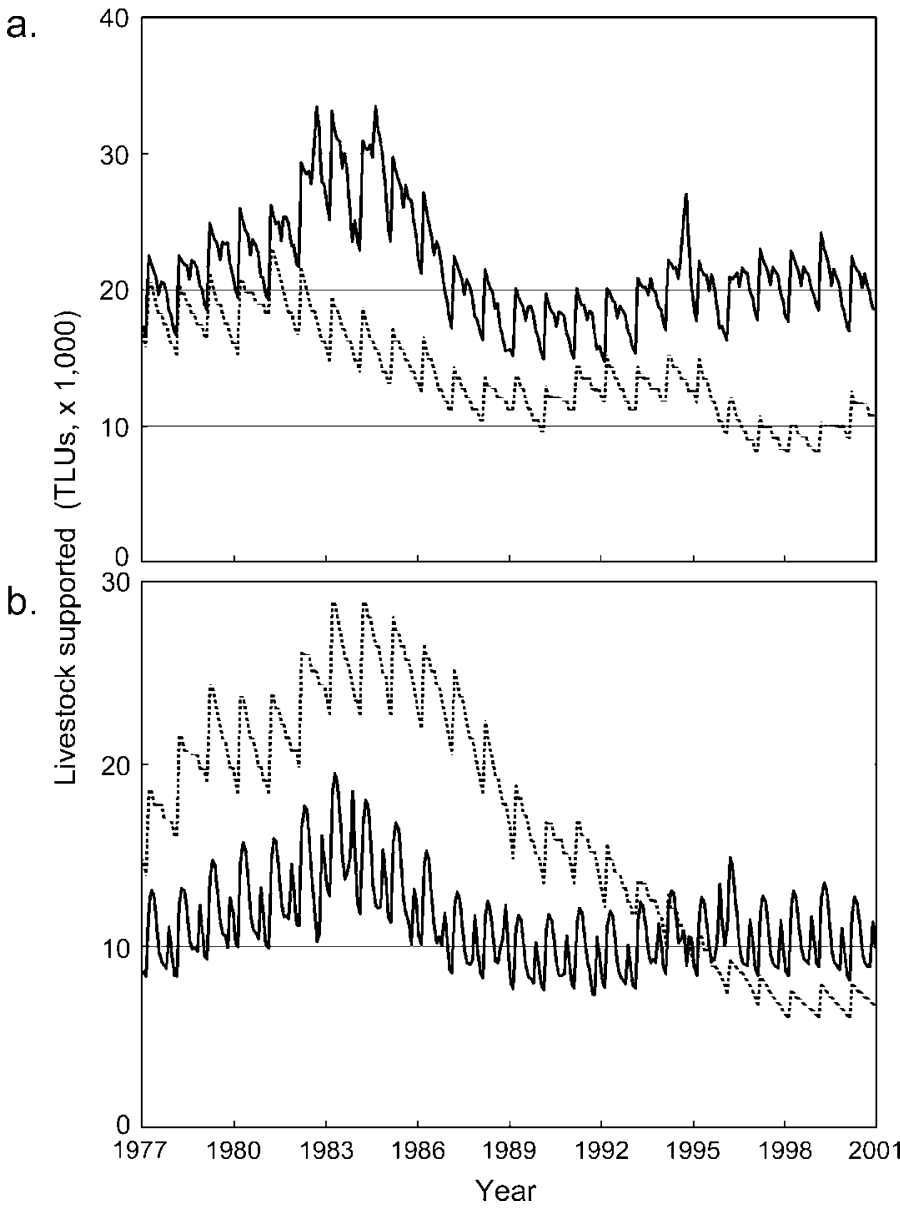

Figure 4. Livestock populations in (a) Imbirikani Group Ranch declined when the ranch was isolated (dotted line) vs. when part of the entire study area (solid line). Livestock on (b) productive Osilalei Group Ranch increased dramatically when isolated (dotted line) vs. when the study area was intact (solid line), until crashing due to overstocking and drought. Simulated responses based on the observed weather pattern are shown.

Olgulului supported 20\% fewer, and Osilalei $9 \%$ more livestock, not significantly different from the group ranch capacity (Fig. 5). In general, standard errors are relatively large (especially for $196 \mathrm{~km}^{2}$ parcels, with $n=5$ ), reflecting sampling within heterogeneous landscapes.

Relative to the intact Eselenkei Group Ranch, the number of livestock that could be supported on the ranch declined steadily as parcel area declined from 10 to $1 \mathrm{~km}^{2}$ (Fig. 6a, for contiguous parcels, shown in black). In contrast, Olgulului Group Ranch, which has low heterogeneity (BurnSilver et al. 2003), showed a similar decline in livestock carrying capacity with parcels from 10 to $1 \mathrm{~km}^{2}$ (Fig. 6b); the decline was not evident at $196 \mathrm{~km}^{2}$ (Fig. 5), but had reached a maximum effect with parcels still large, $10 \mathrm{~km}^{2}$, and did not decline further. The number of livestock that could be supported on the most productive group ranch, Osilalei, did not decline as parcel area was reduced (Fig. 6c).

Allowing herders within Eselenkei to share three, five, or ten $1 \mathrm{~km}^{2}$ parcels that were dispersed on the landscape increased the number of animals that could be supported (Fig. 6a, for 


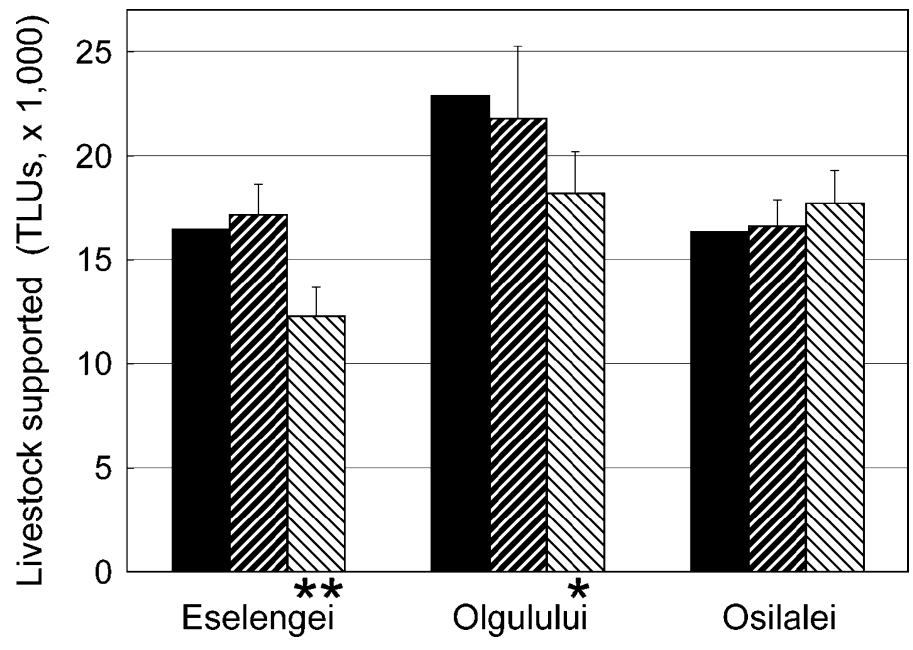

Figure 5. Livestock populations supported on Eselenkei, Olgulului, and Osilalei group ranches when the ranches are intact (solid bars), divided into $196 \mathrm{~km}^{2}$ parcels (heavy shading), and $1 \mathrm{~km}^{2}$ parcels (light hatching), with standard errors based on 5 and 20 samples, respectively. The significance of comparisons to the group ranch mean are shown with symbols $\left({ }^{*}=P<0.05,{ }^{*}=P<0.01\right)$.

dispersed parcels, shown in heavy hatching). In contrast, responses were similar in Olgulului Group Ranch regardless of whether or not parcels were composed of contiguous or dispersed $1 \mathrm{~km}^{2}$ blocks (Fig. 6b). In Osilalei Group Ranch, the effect of sharing parcels composed of dispersed blocks was mixed (Fig. 6c).

\section{DISCUSSION AND CONCLUSIONS}

We hypothesize a humped-shape relationship, with the importance of subdivision relative to herbivore carrying capacity to be: 1) weak for areas of low vegetation productivity and heterogeneity, where nonequilibrial rangeland dynamics dominate (e.g., Ellis and Swift 1988); 2) weak for areas of high vegetation productivity or very high heterogeneity, where forage production is sufficient and stable enough to support animals on small parcels, or heterogeneous forage patches are tightly packed in space, so that small parcels still contain diverse ephemeral patches; and 3) strong for areas intermediate in these attributes (Boone et al., In press). Severe drought might make any parcel uninhabitable, but the hump-shaped response is hypothesized for most years.

In simulations, livestock carrying capacity declined by $25 \%$ when Eselenkei Group Ranch was subdivided into $1 \mathrm{~km}^{2}$ parcels, a dire decrease for Maasai households already facing rising human population and food insecurity (Rutten 1992; GoK 2003). Moreover, current plans to subdivide group ranches in the area entail each ranch member receiving on average a 24 to 40 ha parcel, an area much smaller than the 100 ha $\left(1 \mathrm{~km}^{2}\right)$ blocks modeled here. The loss in livestock carrying capacity from subdivision in some group ranches might therefore be more extreme than our simulations suggest. For more productive group ranches, such as Osilalei, the modeled subdivision had little impact upon carrying capacity. Theoretically, areas of sufficient vegetation productivity throughout the

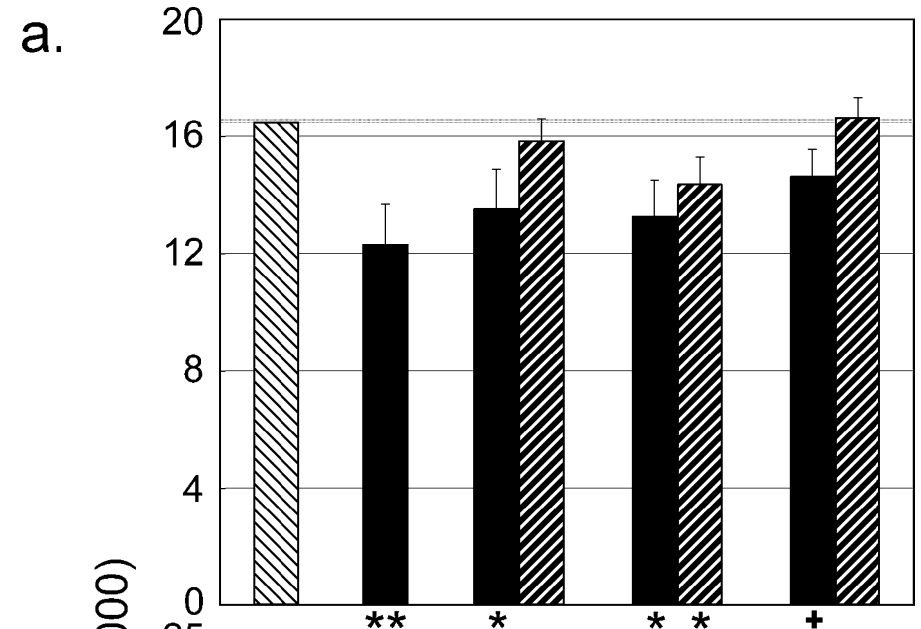

b.

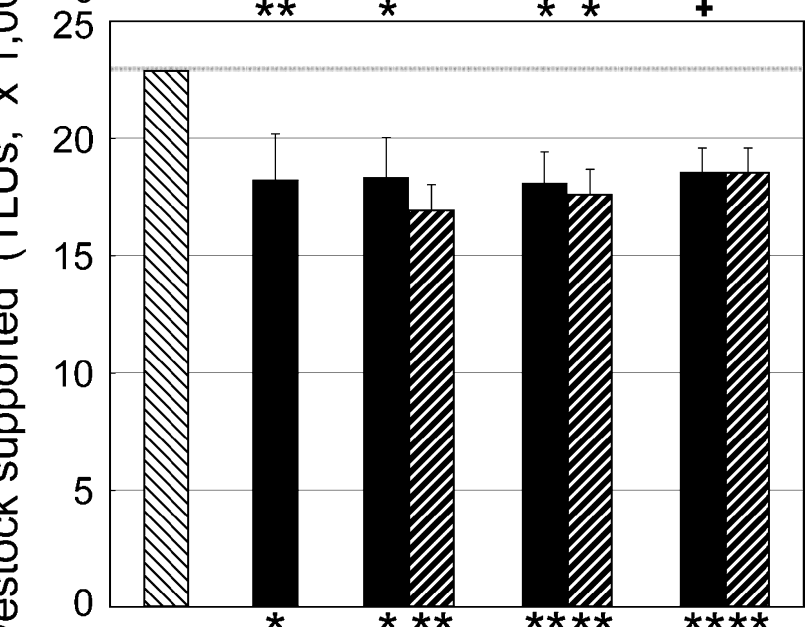

c.

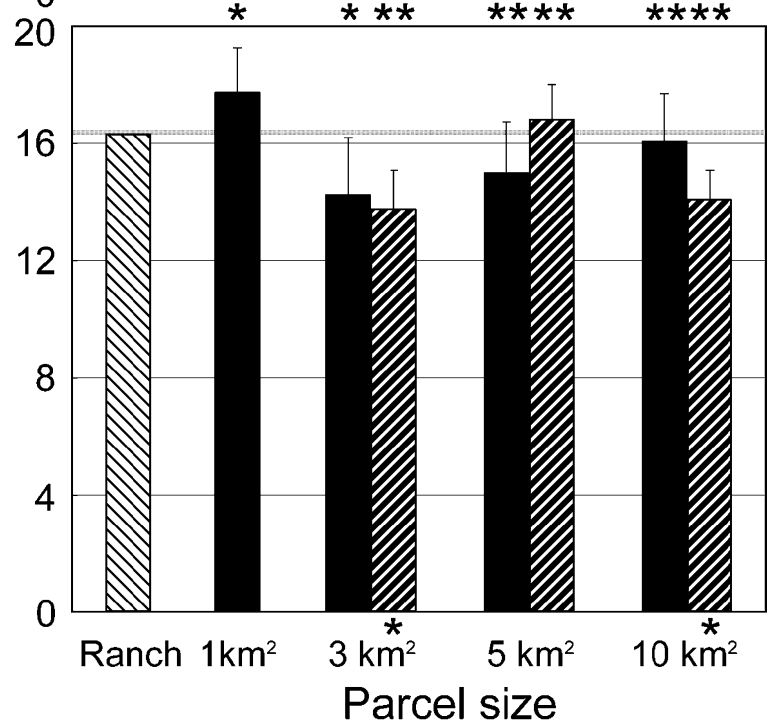

Figure 6. The livestock population that was supported on the intact group ranches (a) Eselenkei, (b) Olgulului, and (c) Osilalei are in the leftmost position (light hatching). That number (indicated by shaded horizontal lines) can be compared to isolation of $1 \mathrm{~km}^{2}$ parcels, or 3 , 5 , and $10 \mathrm{~km}^{2}$ parcels composed of contiguous $1 \mathrm{~km}^{2}$ blocks (solid bars). In turn, the number on contiguous blocks can be compared with livestock supported on parcels composed of randomly dispersed $1 \mathrm{~km}^{2}$ blocks (heavy hatching), with standard errors. The significance of comparisons to the group ranch mean are shown with symbols $\left(+=P<0.10,{ }^{*}=P<0.05,{ }^{* *}=P<0.01\right)$. 
year could support an animal on a small plot, and would be insensitive to effects of subdivision; Osilalei might be approaching that limit, given that capacity of the group ranch is similar whether it is intact or composed of $1 \mathrm{~km}^{2}$ parcels. In contrast, subdivision on relatively unproductive and homogeneous Olgulului Group Ranch reduced capacity even for large 10 $\mathrm{km}^{2}$ parcels, and stayed relatively stable as parcel area declined further. These results indicate that the effects of subdivision will not be the same across all group ranches. This is an important message for both pastoral land users and policy makers as they contemplate subdivision on group ranches with varying levels of rainfall, productivity, and levels of vegetation heterogeneity.

The utility of simulated grazing associations in offsetting losses expected from subdivision varied based upon the spatial heterogeneity of pastures within the group ranches. Participation in a grazing association improved livestock production in Eselenkei, but was not useful in Olgulului Group Ranch. Technically, spatial autocorrelation in vegetation production in Eselenkei was low, leading to dispersed $1 \mathrm{~km}^{2}$ blocks sampling disparate production profiles. In contrast, the spatial autocorrelation of Olgulului was high, so that dispersed $1 \mathrm{~km}^{2}$ blocks sampled vegetation production profiles that changed in unison.

In related analyses, SAVANNA was joined to the PHEWS (Pastoral Household Economic Welfare Simulator) model, which simulated decision making in Maasai households, and was originally applied in Ngorongoro Conservation Area, Tanzania (Thornton et al. 2003). PHEWS is a rule-based model that reflects the decision making processes Maasai use for household economy and food security. Simulations with SAVANNA and PHEWS linked represented Maasai households on parcels in their observed densities, and the well-being of household members declined dramatically in subdivided group ranches, even within large grazing areas of $196 \mathrm{~km}^{2}$ (Thornton et al., In press). Deficits in household income were offset by increased animal sales, thereby reducing herd sizes, which ultimately caused further declines in income and more animal sales, in a declining spiral sometimes seen in Maasai communities (Rutten 1992).

Our approach focused upon comparisons between simulations where the only variable changed between runs was livestock mobility. The model was parameterized to agree with observations to the degree possible, but the approach is not predicated on absolute predictive ability, but rather on comparisons between simulations parameterized identically. We presented the main results discussed here during meetings in Kajiado in 2003 to Maasai pastoralists and agro-pastoralists (in the Maa language) and to Kenyan land managers, with positive feedback from participants indicating that our results were in general agreement with their expectations and experiences, what Rykiel (1996) calls face validity. Results are not intended to provide predictions as to actual livestock population levels 24 years hence, but rather to provide examples of tradeoffs associated with different subdivision options and the direction and magnitudes of expected change. The SAVANnA model is complex, but all models must simplify reality and capture main effects. For example, we excluded supplemental feeding as a response to offset effects of fragmentation. Herbivore populations can be maintained high artificially by feeding hays or other forage. SAVANNA is capable of modeling the effects of supplemental feeding, but supplemental feeding of livestock is very rare in southern Kajiado District, Kenya. We assumed water was accessible from any parcel, although travel costs to reach water were tracked. As lands are further subdivided, however, some recipients will receive parcels that are distant from water and barely suitable for livestock. The cultural norms of the Maasai, small requirement for land (i.e., an access route, vs. large area), and our experience suggests that, in general, water sources will be available to members communally for the foreseeable future, except for places where water sources are very scarce, such as the Chyulu Hills. In contrast, access to key resources are already strained. Some swamps outside Amboseli National Park are fenced as water and natural reserves, and most others have been allocated for agricultural use by group ranch members. Seasonal or episodic access to these key resources by livestock is already under threat.

Parcels were used exclusively by owners in our analyses. This approximates what is seen in group ranches long subdivided, such as in the Kitengela region of Kajiado District, which has many fenced parcels (Kristjanson et al. 2002). In addition, within the ranches we studied, pastoralists were more likely to be sedentary if they occupied a subdivided group ranch, and moved shorter distances each day (BurnSilver et al. 2003). We modeled exclusive use at a larger scale as well. Although instructive, such limitations are counter to the Maasai culture of reciprocity in terms of access to grazing and water resources (although fencing parcels would have been abhorrent in the past, but is done today in subdivided areas). It is telling in this vein that movement of households from subdivided areas to still intact group ranches still occurs. For instance, in the drought of 2000 almost $50 \%$ of Osilalei Group Ranch members negotiated to move temporarily to Imbirikani Group Ranch in search of forage (BurnSilver, unpublished data; Worden, unpublished data). In general, absolute exclusion of nongroup ranch members from ranches seems unlikely, although the trend under subdivision indicates less mobility on average in nondrought years.

In this research, the range of variation in productivity is limited to that on four group ranches. We have not yet quantified in detail how variations in productivity, for example, might relate to effects of fragmentation (e.g., the presence of thresholds). We do appear to have identified one endpoint on a gradient, however, with fragmentation on Osilalei Group Ranch not having a significant effect on stocking rates. Another group ranch exhibited a large decline, $25 \%$ of livestock, under fragmentation to $1 \mathrm{~km}^{2}$, but we hypothesize more extreme losses are possible. Ongoing research will quantify in detail the decline in herbivore carrying capacity for a range of vegetation productivities and variations in rainfall amounts, for multiple ecosystems. We focused upon changes in livestock carrying capacity, but reduced access to land will impact wild herbivores as well (Western and Gichohi 1993). Also, changes in vegetation performance can be expected as animals use innately ephemeral resources on a year-round, intensive basis, instead of periodically as in the past. Results summarizing changes in vegetation under subdivision for these group ranches are in Boone (In press).

We have demonstrated that declines in livestock numbers are associated with the subdivision of Kajiado group ranches into individual parcels. Subdivision might be inevitable (Kimani and Pickard 1998; BurnSilver et al. 2003), but governmental and 
non-governmental organizations might have to encourage diversification or might expect to increase subsidies by $25 \%$ or more to offset additional food insecurity in Maasai associated with subdivision. Grazing associations are one option to maintain flexibility in light of such insecurity, and these should be encouraged by policy makers. Specifically, unless in ranches of very low or high productivity, herd owners should be encouraged to form associations with land owners distributed throughout their group ranches. Moreover, subdivision does impart upon group ranch members benefits, such as title to a parcel of land that may be used as collateral (Kimani and Pickard 1998), but access to other production inputs (e.g., loans for water and other infrastructure development) to offset small parcel sizes is currently very limited. Recognizing that different pathways to subdivision do exist and that subdivision might be inevitable, extreme care is justified in planning, to take into account variable conditions across group ranches and maintain maximum flexibility in options available for grazing households. Our results quantify the relative benefits if land owners and policy makers act to maintain open or flexible access to individually held parcels.

\section{ACKNOWLEDGMENTS}

We thank the Kenyan Department of Resources Surveys and Remote Sensing for providing maps of aerial survey results, and J. Acen of Colorado State University for digitizing the maps. Our deepest thanks as well to Maasai and others that participated in workshops and provided us with information.

\section{LITERATURE CITED}

ADDS. 2004. African Data Dissemination Service. Sioux Falls, SD: U.S. Geological Survey/EROS Data Center. Available at: http://edcsnw4.cr.usgs.gov/adds/. Accessed 18 January 2004.

BeHNKE, R. H., AND I. Scoones. 1993. Rethinking range ecology: implications for rangeland management in Africa. In: R. H. Behnke, I. Scoones, and C. Kerven, [EDS.]. Range ecology at disequilibrium: new models of natural variability and pastoral adaptation in African savannas. London, UK: Overseas Development Institute. p. 1-30.

Bekure, S., P. N. de Leeuw, B. E. Grandin, and P. J. H. Neate (eds.). 1991. Maasai herding: analysis of the livestock production system of Maasai Pastoralists in eastern Kajiado District, Kenya. Addis Ababa, Ethiopia: ILCA (International Livestock Centre for Africa), ILCA Systems Study 4. 172 p.

Boar, R. R., D. M. Harper, and C. S. Adams. 1999. Biomass allocation in Cyperus papyrus in a tropical wetland, Lake Naivasha, Kenya. Biotropica 31:411-421.

BooNe, R. B. 2000. Integrated management and assessment system: balancing food security, conservation, and ecosystem integrity-a training manual. University of California, Davis: Global Livestock Collaborative Research Support Program. Available at: http://www.nrel.colostate.edu/projects/imas/ prods/rboone/Workshop.html. Accessed 5 June 2000.

Boone, R. B. In press. Quantifying changes in vegetation in shrinking grazing areas. Conservation \& Society.

Boone, R. B., S. B. BurnSilver, J. S. Worden, K. A. Galvin, and N. T. Hobbs. In press. Large-scale movements of large herbivores: livestock following changes in seasonal forage supply. In: F. van Langeveld and H. H. T. Prins [EDs.]. Resource Ecology. Dordrecht, The Netherlands: Kluwer Publishing.

Boone, R. B., M. B. Coughenour, K. A. Galvin, and J. A. Ellis. 2002. Addressing management questions for Ngorongoro Conservation Area, Tanzania, using the Savanna modeling system. African Journal of Ecology 40:138-150.

Boone, R. B., K. A. Galvin, M. B. Coughenour, J. W. Hudson, P. J. Weisburg, C. H.
Vogel, AND J. E. ElLIs. 2004. Ecosystem modeling adds value to a South African climate forecast. Climatic Change 64:317-340.

Boone, R. B., AND N. T. HoBBS. 2004. Lines around fragments: effects of fencing on large herbivores. African Journal of Range \& Forage Science 21:147-158.

BurnSilver, S., R. B. Boone, and K. A. Galvin. 2003. Linking pastoralists to a heterogeneous landscape: the case of four Maasai group ranches in Kajiado District, Kenya. In: Fox, J., V. Mishra, R. Rindfuss, and S. Walsh (EDs.). Linking household and remotely sensed data: methodological and practical problems. Boston, MA: Kluwer Academic Publishing. p. 173-199.

Coughenour, M. B. 1985. Graminoid responses to grazing by large herbivores: adaptations, exaptations, and interacting processes. Annals of the Missouri Botanical Garden 72:852-863.

Coughenour, M. B. 1992. Spatial modelling and landscape characterization of an African pastoral ecosystem: a prototype model and its potential use for monitoring drought. In: D. H. McKenzie, D. E. Hyatt, and V. J. McDonald [EDS.]. Ecological Indicators, Vol. 1. New York, NY: Elsevier Applied Science. p. 787810.

Coughenour, M. B., J. E. Ellis, and R. G. Popp. 1990. Morphometric relationships and development patterns of Acacia tortilis and Acacia reficiens in Southern Turkana, Kenya. Bulletin of the Torrey Botanical Club 117: 8-17.

De Haan, C., H. Steinfeld, and H. Blackburn. 1997. Livestock and the environment: finding a balance. Brussels, Belgium: Commission of the European Communities, Food and Agricultural Organization of the United Nations, and the World Bank. 115 p.

De Leeuw, J., H. H. T. Prins, E. C. Nuuguna, M. Y. Said, and R. A. de By. 1998. Interpretation of DRSRS animal counts (1977-1997) in the rangeland districts of Kenya. Enschede, The Netherlands: International Institute for Aerospace Survey and Earth Sciences, Enschede, and Nairobi, Kenya: Department of Resource Surveys and Remote Sensing. $187 \mathrm{p}$.

ElLIS, J. E. 1993. Climate variability and complex ecosystem dynamics: implications for pastoral development. In: Scoones, I. [ED.]. Living with uncertainty: new directions in pastoral development in Africa. London, UK: Intermediate Technology Publications. p. 37-46.

Ellis, J. E., AND D. M. Swift. 1988. Stability of African pastoral ecosystems: alternative paradigms and implications for development. Journal of Range Management 41:450-459.

faO (Food and Agriculture Organization of the United Nations). 2001a. Pastoralism in the new millennium. Animal Production and Health Paper 150. Rome, Italy: FA0. 104 p.

fa0 (Food and Agriculture Organization of the United Nations). 2001b. The AfriCover Initiative. AfriCover East Africa Module, Nairobi, Kenya. Available at: http:// www.africover.org/index.htm. Accessed 26 May 2001.

FouRIE, J. H., AND B. R. RoberTs. 1977. Seasonal dry matter production and digestibility of Themeda triandra and Eragrostis lehmanniana. Agroplantae 9:129-133.

GalATY, J. G. 1994. Ha(I)ving land in common: the subdivision of Maasai group ranches in Kenya. Nomadic People 34/35:109-122.

GoK (Government of KenYA). 2003. Geographic dimensions of well-being in Kenya. Volume 1: Where are the poor? From districts to locations. Nairobi, Kenya: Ministry of Planning and National Development, Central Bureau of Statistics.

Grandin, B. E. 1989. Land tenure, subdivision, and residential change on a Maasai group ranch. Economic Anthropology 2:9-13.

GroombridGE, B. 1992. Global biodiversity: status of the Earth's living resources. London, UK: Chapman \& Hall. 585 p.

Hodgkinson, K. C., M. M. Ludlow, J. J. Mott, and Z. Baruch. 1989. Comparative responses of the savanna grasses Cenchrus ciliaris and Themeda triandra to defoliation. Oecologia 79:45-52.

Homewood, K. M., and W. A. Rodgers. 1987. Pastoralism, conservation, and the overgrazing controversy. In: D. Anderson and R. Grove [EDS.]. Conservation in Africa: people, policies and practice. Cambridge, MA: Cambridge University Press. p. 111-128.

Kalemera, M. C. 1989. Observations of feeding preferences of elephants in the Acacia tortilis woodland of Lake Manyara National Park, Tanzania. African Journal of Ecology 27:325-333. 
Kenya Soll Survey. 1995. 1:1M scale soil and terrain database of Kenya (KenSOTER). Nairobi, Kenya: Ministry of Agriculture.

KImanI, K., AND J. PICKARD. 1998. Recent trends and implications of group ranch sub-division and fragmentation in Kajiado District, Kenya. Geography Journal 164:202-213.

KınYamario, J. I. 1996. NPP Grassland: Nairobi, Kenya, 1984-1994. Oak Ridge National Laboratory, Distributed Active Archive Center. Oak Ridge, TN: Available at: http://www.daac.ornl.gov. Accessed 7 March 2003.

Kristuanson, P., M. Radeny, D. Nkedianye, R. Kruska, R. Reid, H. Gichohi, F. Atieno, AND R. SANFORD. 2002. Valuing alternative land-use options in the Kitengela wildlife dispersal area of Kenya. International Livestock Research Institute (ILRI) Impact Assessment Series 10. Nairobi, Kenya: A joint ILRI/African Conservation Centre Report. $53 \mathrm{p}$.

McNaughton, S. J. 1985. Ecology of a grazing ecosystem: the Serengeti. Ecology Monographs 55:259-294.

MurRaY, M. G. 1995. Specific nutrient requirements and migration of wildebeest. In: Sinclair, A.R.E. and P. Arcese [EDS.]. Serengeti II: Dynamics, management, and conservation of an ecosystem. Chicago, IL: University of Chicago Press. p. 231-256.

MwalyosI, R. B. B. 1992. Influence of livestock grazing on range condition in southwest Masailand, Northern Tanzania. Journal of Applied Ecology 29:581-588.

Mwangl, L. N. 1994. Optimization of pastoral subsistence strategies under drought and marketing risks: Maasai model ranch study [dissertation]. Fort Collins: Colorado State University. $131 \mathrm{p}$.

Ndawula-Senyimba, M. S. 1972. Some aspects of the ecology of Themeda trianda. East African Agriculture and Forestry Journal 38:83-93.

Niamir-Fuller, M., and M. D. Turner. 1999. A review of recent literature on pastoralism and transhumance in Africa. In: Niamir-Fuller, N. [ED.]. Managing mobility in African rangelands: the legitimization of transhumance. London, UK: Intermediate Technology Publications, Ltd. p. 18-46.

O'ConnoR, T. G. 1994. Composition and population responses of an African savanna grassland to rainfall and grazing. Journal of Applied Ecology 31:155-171.

Oesterheld, M., C. M. DiBella, and H. Kerdiles. 1998. Relation between NOAAAVHRR satellite data and stocking rate of rangelands. Ecological Applications 8:207-212.

Ole Katampol, K., G. Genga, M. Mwangi, J. Kipkan, J. Ole Seitah, M. K. van Klinken, And M. S. Mwangl. 1990. Kajiado District atlas. Kajiado, Kenya: ASAL Programme Kajiado and the Ministry of Reclamation and Development of Arid, Semi-Arid Areas and Wastelands. 123 p.

Pickup, G., and D. M. Stafford Smith. 1993. Problems, prospects and procedures for assessing the sustainability of pastoral land management in arid Australia. Journal of Biogeography 20:471-487.

Prins, H. H. T., ANd H. P. van deR JeUgd. 1993. Herbivore population crashes and woodland structure in East Africa. Journal of Ecology 81:305-314.
Ritchie, M., And H. OLff. 1999. Spatial scaling laws yield a synthetic theory of biodiversity. Nature 400:557-560.

RutTen, M. M. E. M. 1992. Selling wealth to buy poverty: the process of the individualization of land ownership among the Maasai pastoralists of Kajiado District, Kenya, 1890-1990. Fort Lauderdale, FL: Verlag Breitenbach Publishers, Saarbrücken. $510 \mathrm{p}$.

RYKIEL, E. J. 1996. Testing ecological models: the meaning of validation. Ecological Modeling 90:229-244.

SeVP (Savanna Elephant Vocalization Project). 2002. SeVP's home ground. Nairobi, Kenya. Available at: http://www.elephantvoices.org. Accessed 28 February 2002.

Sinclair, A. R. E., And M. D. Gwynne. 1972. Food selection and competition in the East African buffalo (Syncerus caffer Sparrman). East African Wildlife Journal 10:77-89.

Staples, R. R., H. E. Horndy, and R. M. Horndy. 1942. A study of the comparative effects of goats and cattle on a mixed grass-bush pasture. East African Agricultural Journal October:62-71.

TEWARI, V. P. 1996. Developing equations for estimating growth parameters of Acacia tortilis (Forsk.) Hayne. Indian Forestry 122:1004-1009.

Thornton, P. K., S. B. BurnSilver, R. B. Boone, and K. A. Galvin. In press. Modelling the impacts of group ranch subdivision on agro-pastoral households in Kajiado, Kenya. Agricultural Systems.

Thornton, P. K., K. A. Galvin, and R. B. Boone. 2003. An agro-pastoral household model for the rangelands of East Africa. Agricultural Systems 76:601-622.

Toxopeus, A. G., X. Bakker, and A. Kariuki. 1994. An interactive spatial modelling (ISM) system for the management of the Amboseli Biosphere Reserve (southeast Kenya). ITC Journal 1994:392-400.

Van WiJngaARDEN, W. 1985. Elephants, trees, grass, grazers: relationships between climate, soils, vegetation, and large herbivores in a semi-arid savanna ecosystem (Tsavo, Kenya). Enschede, The Netherlands: Department of Natural Resources, Surveys, and Rural Development of the International Institute for Aerospace Survey and Earth Sciences, ITC Publication \#4. 159 p.

Verma, D. N., A. K. Verma, and 0. M. Prakash. 1997. Nutritive value of nut grass (Cyperus rotundus) for goat. Indian Veterinary Journal 74:100.

WeSteRn, D. 1975. Water availability and its influence on the structure and dynamics of a savannah large mammal community. East African Wildlife Journal 13:265-286.

Western, D., AND H. GichoH. 1993. Segregation effects and the impoverishment of savanna parks: the case for ecosystem viability analysis. African Journal of Ecology 31:269-281.

XiE, P., AND P. A. ARKin. 1997. A 17-year monthly analysis based on gauge observations, satellite estimates, and numerical model outputs. Bulletin of the American Meteorological Society 78:2539-2558. 